\title{
GAMIFICATION AND FIRMS \\ COMPETITIVENESS: AN ANALYSIS OF DEPOSIT MONEY BANKS
}

\section{GAMIFIKACIJA I KONKURENTNOST PODUZEĆA: ANALIZA KOMERCIJALNIH BANAKA}

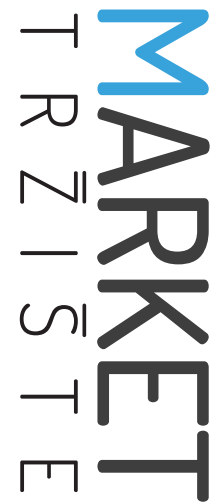

\author{
Market-Tržište \\ Vol. 33, No. 2, 2021, pp. 129-147 \\ UDK 004.94:794:339.137.2:336.71 \\ DOl http://dx.doi.org/10.22598/mt/2021.33.2.129 \\ Preliminary communication
}

\author{
Powel Maxwell Worimegbe $^{a}$, Temitope Mariam Worimegbe ${ }^{b}$, Oyinlola Akinyede \\ a Olabisi Onabanjo University, Ogun State, NIGERIA, e-mail: powelmaxwell@yahoo.com \\ ${ }^{\text {b }}$ Redeemers University, Osun State, NIGERIA, e-mail: worimegbet@run.edu.ng \\ cRedeemers University, Osun State, NIGERIA, e-mail: akinyedeo@run.edu.ng
}

\begin{abstract}
Purpose - This study investigates the influence of gamification on the competitiveness of financial sector companies. The dimensions of gamification related to financial services are premised on product development, marketing and sales activities, and customer services.
\end{abstract}

Design/Methodology/Approach - Employing the survey research design, 662 bank employees of Nigerian banks forming the sample took part in the research by filling out structured questionnaires. The partial least square structural equations model was utilised in the analysis of data in the study.

Findings and Implications - The result reveals that gamification dimensions positively affect competitiveness. The findings further indicate that product development, marketing and sales activities, and customer service positively and significantly affect the firm's competitiveness. The practical implication of this is that deposit money banks should pay attention to gamification to maintain competitiveness. More attention should also be paid to credit sourcing, referrals and lead generation, and selfhelp application in order for firms to achieve and maintain competitiveness.

Limitations - This study examined the gamification impact on competitiveness using the banking sector as a

\section{Sažetak}

Svrha - Rad istražuje utjecaj gamifikacije na konkurentnost poduzeća u financijskom sektoru. Dimenzije gamifikacije povezane s financijskim uslugama temelje se na razvoju proizvoda, marketinškim i prodajnim aktivnostima te uslugama korisniku.

Metodološki pristup - $U$ anketnome istraživanju sudjelovalo je 662 zaposlenika nigerijskih banaka, a korišten je strukturirani anketni upitnik. $U$ analizi podataka prikupljenih istraživanjem primijenjeno je PLS modeliranje strukturnih jednadžbi metodom parcijalnih najmanjih kvadrata (PLS).

Rezultati i implikacije - Rezultati pokazuju da dimenzije gamifikacije pozitivno utječu na konkurentnost poduzeća. Nadalje, rezultati naznačuju da razvoj proizvoda, marketinške i prodajne aktivnosti te usluge korisnicim pozitivno i značajno utječu na konkurentnost poduzeća. Praktična implikacija rada jest da komercijalne banke za održavanje konkurentnosti trebaju obratiti pozornost na gamifikaciju. Isto je tako potrebno posvetiti više pozornosti izvorima kredita, preporukama i generiranju potencijalnih korisnika te samopomoći radi postizanja i održavanja konkurentnosti poduzeća.

Ograničenja - Rad je istraživao utjecaj gamifikacije na kurentnost poduzeća koristeći bankarski sektor kao kon- 
Powel Maxwell Worimegbe, Temitope Mariam Worimegbe, Oyinlola Akinyede

theatre of the study. The study employed non-financial measures of competitiveness in arriving at conclusions.

Originality - The study provides an insight into how gamification can be significantly put into practice in real-life scenarios and businesses to achieve competitiveness.

Keywords - banking industry, gamification, financial services, firms' competitiveness, marketing tekst. Pri donošenju zaključaka primijenjene su nefinancijske mjere konkurentnosti.

Doprinos - Rad pruža uvid u to kako se gamifikacija može značajno primijenitiu praksi u stvarnim situacijama i poduzećima radi postizanja konkurentnosti.

Ključne riječi - bankarska industrija, gamifikacija, financijske usluge, konkurentnost poduzeća, marketing 


\section{INTRODUCTION}

Improving the behavior of firms as they try to achieve their strategic goals considering the market dynamics and environmental complexities has been the focus of many firms in most recent times. Financial services providers are concerned with how value creation could engage and retain existing customers while capturing potential ones. Stefanel and Goyal (2018) assert that service providers such as telecommunication companies and banks consistently have wide economic moats, premised on attracting customers. However, their strategies have been ineffective in retaining customers who are poached away easily by their competitors. Gamification has become a new strategy employed by firms to achieve their corporate goals both in the short term and in the long run (Mruthyanjaya \& Vadiya, 2019; Warnick \& Bui, 2019).

Gamification is gradually gaining recognition in the field of management and strategic analysis. Gartner (2011) believes that through gamification companies utilize game mechanisms to motivate and digitally engage people in achieving their goals. The idea of gamification is premised on customer centricity, that is, it deals with appealing to the stated and unstated desires of the customers. Gamification involves appealing to customers' impulses, such as social interaction, rewards, competition, desires as well as their need for simplicity, engagement, entertainment, ease, and fun to achieve favourable outcomes for both customers and the firm.

According to Stefanel and Goyal (2018), it is evident that critical aspects of value creation in company operations are shifting towards customer retention and engagement. More customer-centric businesses have short-circuited firms that have not been proactive in the dynamic business environment. Upstream value chain activities, that were seen as an integral part of business operations, have become "non-core" and are fast losing their share in industry economics. Gamification, as a downstream strategic phenomenon, gradually entices firms to engage their existing and potential customers using techniques that enable them to achieve their objectives, thereby retaining a larger share of industry economics.

Various studies have confirmed the impact of gamification on a firm's sales performance, operational efficiency of employees, social business transformation, and performance management (Worimegbe, Worimegbe \& Abiola-Oke, 2020; Mruthyanjaya \& Vadiya, 2019; Warnick \& Bui, 2019; Yussuf, Oladimeji, Ahmodu \& Adeniyi, 2019; Biloch \& Lofstedt, 2013; Maan, 2013). However, its effect on the competitiveness is yet to be established in the literature. A firm's competitiveness is influenced by the idea that the firms striving to deliver superior quality services will meet customer expectations and make it difficult for customers to opt for the services of their competitors. Klapalova (2013) found that a consistent measure of performance in terms of profit of a firm does not indicate that a firm is prosperous since its profit is a short-term measure while competitiveness is a long-term measure. Competitiveness reveals the true nature of how a firm survives in the dynamic business environment in which it exists.

The question of what gamification is has already been addressed in the literature (Huotari \& Hamari, 2012; Worimegbe et al., 2020). Ng (2011) points to an ongoing debate about how gamification can be dramatically applied by enterpsrises in real-life situations to achieve competitiveness. Therefore, this study analyses the trends in banking industry gamification to explore the influence of gamification dimensions on company competitiveness. It also seeks to determine the gamification factor, which most significantly affects the competitiveness of firms. The following research questions were posed for the purpose of achieving the goals of this study:

1. To what extent does product development gamification affect firms' competitiveness in deposit money banks?

2. How do marketing and sales gamification activities influence firms' competitiveness in deposit money banks? 
3. To what degree does customers service gamification affects firms' competitiveness in deposit money banks?

\section{LITERATURE REVIEW}

\subsection{Gamification in the banking industry}

Gamification is a strategy which deals with applying the components of game principles and design into a non-gaming environment. Joudrey (2019) believes that gamification strategies are a perfect tool for customer engagement in the banking industry, with gamification motivating the existing customers to keep using company services while attracting potential customers. Gamification has the potential to transform the face of traditional banking into a more competitive way of doing business. The constant desire to meet customer expectations and increase their loyalty has driven banks to gamify. The increasing cost of acquiring customers and fierce competition has challenged banks to develop new techniques to engage their customers while capturing most of their behavior (Querrec, 2015; Rodrigues, Costa \& Oliviera, 2014). Banks have started viewing gamification as a tool for achieving better business performance in the future because it can motivate them to transform dull traditional activities into more exciting, interesting, and entertaining ones. Gamification is premised on the idea that customers should be engaged and motivated to perform certain activities which will add value to them using the gaming mechanics and principles.

Gamification is not a new concept in banking; it has always been an integral aspect of bank setup but is now growing thanks to being driven by customer behavior and increasing technological capabilities. Gamification in the banking industry will enable customers to indicate their preferences and needs, thereby reducing challenges they usually encounter. This creates better opportunities for banks to be more pro- active in meeting the needs of their customers while being more accurate in developing products, marketing actions, and services tailored to meet the customer needs (Stefanel \& Goyal, 2018). Babrovich (2017) posited that gamification has the potential to boost customer deposits, expand their awareness of new services and products, simplify complex banking deliverables, and instil financial literacy among existing and potential bank customers. $\mathrm{Xu}$, Weber, and Buhalis (2017) pointed to a dearth of empirical literature showing how gamification could determine or drive firms' expected outcome. According to Oleksyuk (2019), banks get involved in gamification by integrating gaming techniques in customer engagement, disseminating information on certain business operations, increasing customer loyalty, and innovation management. However, whether financial institutions can profit from gamification in the same way that other businesses have done is debatable. In financial services, gamification details are available in innovation management, talent management, marketing, and sales (Stefanel \& Goyal, 2018). Moreover, corporate banking business gamification is just as effective as consumer banking business gamification. The same is true of social and non-traditional banks: fierce competition helps to level the playing field. Banks making progress in gamification are those that apply gamification principles and elements carefully and methodically. This is because a bank's size and its assets are not the most important factors in attracting and retaining customers (Worimegbe et al., 2020).

\subsection{Operationalisation of gamification}

The need for firms to continually engage their customers has been identified as one of the gamification drivers (Perusic, 2008; Amato-McCoy, 2005). Gamification as a strategy appeals to people's natural desires and impulses, such as the need for social interaction, fun, simplicity, competition, and reward. As indicated by Worimegbe and others (2020), gamification in bank- 
ing is an important philosophy to adapt. This is predicated on the belief that there is a reason why multibillion-dollar corporations invest in gamification. Such corporations understand that gamification is not just about obtaining coins, badges, or tokens; rather, it is also about obtaining valuable analytical data, expanding customer portfolio, and projecting a positive and more appealing image (Oleksyuk, 2019).

Undeniably, there are difficulties that may be encounted in pursuing this strategy. Banks wishing to adopt gamification in their value proposition must significantly modify their internal processes, mechanisms, and operational activities. However, stakeholders in the banking industry must implement gamification strategically to achieve the full capability of digitalisation. The gamification strategy can be employed to make traditional transactions fun, market services, educate consumers extensively, and strategically map functional benefits to customers' advantage. Oleksyuk (2019) believes that gamification in the banking industry exists in the form of marketing and sales, innovation, customer services, and product development. The present study utilises product development, marketing activities, and customer services as the measures of gamification. These measures, already established in the studies by Oleksyuk (2019) and Stefanel and Goyal (2018), represent the current strategies used in the Nigerian banking industry.

The product development gamification strategy involves the ability of the firm to create more products and services geared towards giving the customers a new experience. Its dimensions cover credit sourcing, market research, inter-company collaboration, and credit scoring ideas (Gomanthi, 2017). The marketing and sales gamification dimension of gamification deals with the ability of the firms to raise customer awareness of different services and communicate that such product and services meet the needs of their customers. It involves need-based cross-selling, referrals and lead generation, directed and engaged marketing, and customer education (Stefanel \& Goyal, 2018; Querrec, 2015; Sawhney, 2006). The customer service gamification dimension shows how the firm responds to the customers, both satisfying and anticipating their needs. It involves interactive self-help applications, catalysing customer behavior, interactive and responsive customer communication.

It is pivotal to investigate the interaction of these dimensions and ascertain the motivation of these firms in applying such a strategy in their operation. Employing and successfully implementing the gamification strategies hinges on the belief that providing a memorable experience to the customers could lead to better performance, enhanced service delivery, and improved service encounter by the firm in achieving its corporate goals (Worimegbe et al., 2020). It is critical to emphasise that gamification does not consist of playing literal games; rathe, it can help a firm understand the need to facilitate positive experience and behavior in customers by promoting and encouraging competitive behavior that excites them.

\subsection{Firm competitiveness}

Maune (2014) explained that the success and survival of a firm in a dynamic and turbulent environment depend strongly on its competitiveness. Firm competitiveness is a multidimensional construct in which measurement is determined by the industry in which a firm exists and the strategy employed by the firm to remain relevant both in the short and the long run. Due to globalisation, firms need to integrate new approaches in identifying windows of opportunities through which they can capture both the local and international markets (Marín, Rubio \& Maya, 2012; Vilanova, Lonanzo \& Arenas, 2009). Strategies focused on competitors are pivotal to the firm's survival. Firm competitiveness is the capacity of a firm to design, produce, and introduce superior products and services to the market considering non-price and price qualities. Porter (2008) posits that nations in the global village can only compete if their firms compete 


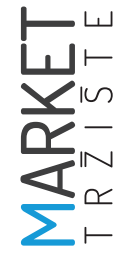

and that it is the firms that compete in the international market, not the countries.

Competitiveness is premised on the idea that a firm strategy must match its internal capabilities and external opportunities to provide a channel of sustained competitive advantage through which the firm can attain its goals, such as market share and profitability. However, Klapaova (2011) maintained that measuring competitiveness in non-financial terms is the key to a firm remaining relevant in the long run since financial measures only indicate the ability of the firm to survive in the short term. Competitiveness in this study will be measured in price and non-price qualities. According to Frohberg and Hartmann (1997), the price and non-price measures are robust and can reveal the true nature of competitiveness. The price, innovation, quality, and customer satisfaction dimensions of competitiveness have been adapted in this study. These measures provide critical additional information for the firm and indirectly reveal the weaknesses, strengths, and opportunities available in its operations (Ahmad \& Zabri, 2016).

\subsection{Development of hypotheses - Gamification and firm competitiveness}

In order to reap the full potential benefits of employing gamification, financial service firms will have to critically evaluate their processes, transform their organisational structure, and align their process and culture to the gamification requirements. Financial service firms use gamification to develop cognitive services which identify existing and potential customer needs (Stefanel \& Goyal, 2018). In terms of product development gamification, banks utilise gamification in inter-company collaboration, market research, credit sourcing, and credit scoring. Oleksyuk (2019) claimed that the gamification of retail banking services is not different from corporate banking services, with digital banking not differing from traditional banking as the intensity of competition among firms in the banking industry evens the odds. A firm that seeks to maintain its competitiveness should strategically design services with game elements. These elements include improving customer experience, gaining customer trust, acquiring customers faster and accessing more customer data. Klaus and Maklan (2013) suggest that firms should apply gamification to improve customer experience. By using gamification in banking, customers would enjoy a better service; more depositors would be attracted while tailored products and services would be made available to customers.

Banks are becoming vulnerable to a shift in the downstream value end of their customers. Traditional financial institutions have increased profitability without changing their strategies due to the regulation and switching cost barriers. However, these strategies have severed a connection between what the banks offer and customer expectations. Banks' inability to meet latent customers expectations and advancements in technology leading to alternative financial services provide incentives for customers to migrate to other banks. While various studies have established the impact of gamification on a firm's sales performance, operational efficiency of employees, social business transformation, and performance management, customer experience and organisational performance (Worimegbe et al., 2020; Mruthyanjaya \& Vadiya, 2019; Warnick \& Bui, 2019; Yussuf et al., 2019; Biloch, 2013; Maan, 2013), its effect on the firm's competitiveness is yet to be established in the literature. The interaction dimensions of product development, marketing and sales activities, customer service and competitiveness is yet to be established in the existing literature. Based on the findings by Worinegbe and others (2020), the dimensions of gamification (e.g., product development, marketing and sales activities, customer service) are expected to drive competitiveness of deposit money bank. Such position is also influenced by arguments of Stefanel and Goyal (2018), who posit that, in order for firms to attain competitiveness, there is a need to critically implement product the development, marketing and sales, and customer ser- 
vice strategy as well as maintaining that there is a need to determine empirically if these strategies could drive performance.

The following hypotheses were proposed based on the gap in the existing literature mentioned above:

H1: Product development gamification has a significant effect on firm competitiveness.

H2: Marketing and sales gamification have a significant effect on firm competitiveness.

H3: Customer service gamification has a significant effect on firm competitiveness. values and consequences of the application represented by a hierarchical model (Copetti, 2005; Kaminski \& Prado, 2005; Dibley \& Baker, 2001). Furthermore, the theory is premised on the assumption that customers view services as a means to meeting important ends, so it tries to describe how the choice of service enhances the desired achievement of an end (Leão \& Mello, 2003; Mulvey, Olson, Celsi \& Walker, 1994). Level as a term explains the hierarchical categorisation of the contents of the service, ranging from service attributes to personal values (Gutman, 1981). Hence, the higher the hierarchical level, the more does the abstraction level grow.

FIGURE 1: Link between gamification and firm competitiveness

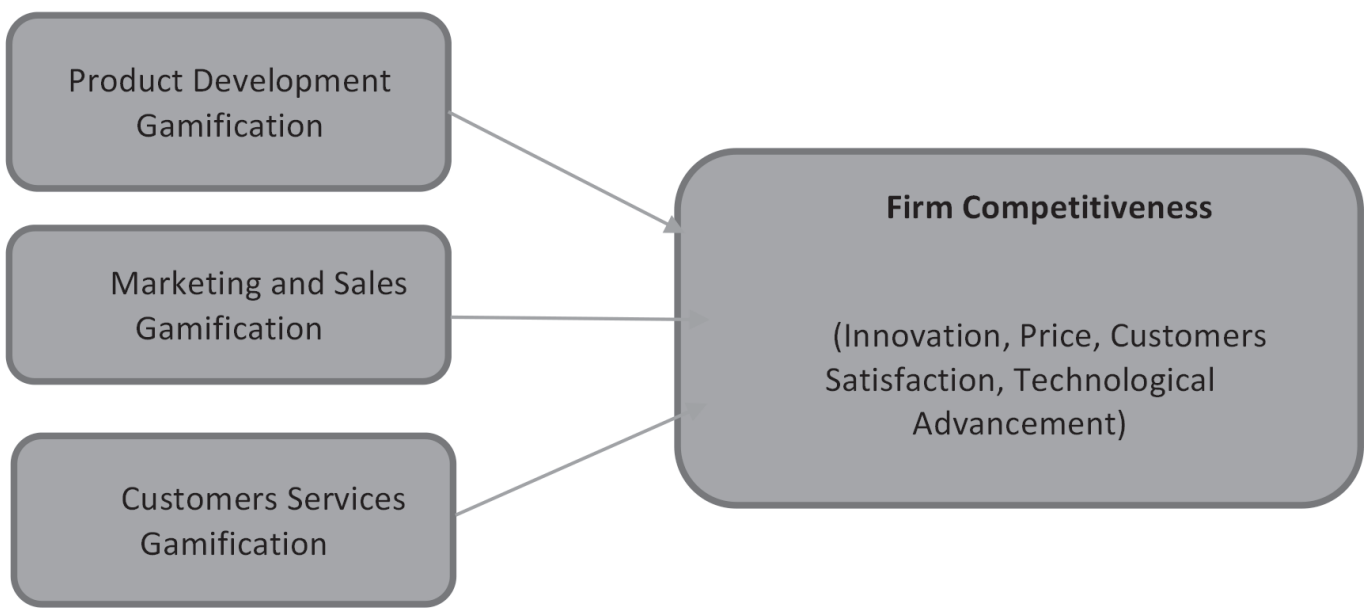

Figure 1 shows the the dimensions of gamification, that is, how product development gamification, marketing and sales gamification, and customer service gamification affect the dimensions of competitiveness: innovation, price, customer satisfaction, and technological advancement. Gamification is expected to interact positively with firm competitiveness.

\subsection{Theoretical framework - Means-end theory}

This study is anchored on the means-end theory developed by Gutman (1981). The theory is based on the idea that the disposition of customers to use a product or a service can be viewed through product attributes, personal
The cooperative link in the means-end model makes possible the analysis and interpretation of customers' perception of services as self-relevant and goes beyond functional attributes to add value to the customers. This theory supports the idea that values are the major factors in the customer purchase pattern. The theory established that there is a link between service attributes and the consequences of such customers' actions. Customers perceive services offered and delivered as satisfying and adding value based on their functionality.

The central idea of the means-end theory is that consumer decisions, suggestions and contributions to firm products and services produce positive consequences and minimise adverse 


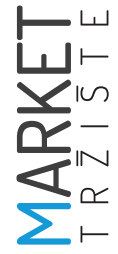

outcomes. The framework of the theory is premised on attributes, consequences, and values (Vriens \& Hofstede, 2000). The means-end theory has been adopted for this study because it connects gamification to the outcome of a firm operation which, in this case, is competitiveness. Firms' product development and customer service activities are based on the perceived disposition of customers to use the products and services rendered by firms. A firm's strategies should be driven to create values that will expand customer engagement and improve their perception of encountering the firm's services and products.

\section{METHODOLOGY}

The survey type of research design was used to obtain data on the banking industry in Nigeria. In December 2019, the Nigerian banking industry consisted of 23 banks. According to the $\mathrm{Ni}$ gerian Bureau of Statistics, the total number of employees in these banks (NBS, 2019) stood at 104,669. Utilising the Raosoft sample size estimator at a 95\% confidence level and 5\% margin of error, the sample size was estimated at 662. Based on the opinion of Hair, Anderson, Tatham, and Black (2010), we considered that sample size to appropriate for the purposes of this study. According to these authors, a sample size of $\geq 400$ is sufficient to decrease the element of the measurement errors in such a way that minor variations are considered statistically significant. The primary source of data were questionnaires distributed to the employees of the 23 banks selected for the survey. The questionnaires were distributed equally among the three categories of banks (international, national and regional) in Lagos, Nigeria. The choice of Lagos was influenced by the fact that it has the highest number of deposit money branches, with all the banks having their corporate headquarters there. The deposit money banks in focus are heterogeneous, so the employees from each deposit money bank were included in the sample to ensure adequate representation. The research instrument was self-administered by the employees of deposit money banks' top management with the help of trained research assistants. The questionnaire was designed to collect answers on a seven-point Likert scale, ranging from $1=$ strongly disagree to $7=$ strong ly agree, allowing us to optimise its reliability. Based on previous studies (Oleksyuk, 2019; Stefanel \& Goyal, 2018), 28 paired items grouped into three dimensions (product development gamification, marketing and sales gamification, and customer service gamification) were used to measure gamification. Sixteen items adopted from the study of Klapaova (2011) and modified by the researchers were employed to measure competitiveness, grouped into innovation, price, customer satisfaction, and technological advancement. A total of 529 (79.9\%) filled-in questionnaires were returned; they were considered satisfying and sufficient based on the criteria established by Hair and others (2010) for the subgroup and multivariate analysis.

Face and construct validity were ensured in the study. The research instrument was tested by independent evaluators, who are expert in finance and business administration, to establish face validity. The confirmatory factor analysis (CFA) was employed to assess the construct validity of each item in the research. The test-retest method was applied by administering the research instrument twice on a selected set of respondents at different times. The first and second pilot tests were correlated, giving a Cronbach alpha of $a=0.768,0.821,0.776,0.733,0.872$, 0.833, and 0.911 for product development, marketing and sales activities, customers services, price, innovation, customer satisfaction, and technology. According to George and Mallery (2000), these results are highly acceptable. The multivariate analysis was utilised to clarify and establish the relationships and interactions between the gamification dimensions and firm competitiveness in this study. This was aimed at strengthening the researchers' arguments in evaluating the most important observed gamification construct that explains the competitive- 
ness of firms. It also provides an insight into the nature and cause of the most observed variable of competitiveness in firms caused by gamification. Therefore, the partial least squares structural equation model (PLS-SEM) was employed to describe the connections, path intensity and to test how the models best match the data. The cause-effect interaction among the variables was measured using the SMARTPLS 3.2.2 statistical tool.

\subsection{Model specification}

The theory underpinning the model for this study is the means-end theory based on the studies by Stefanel and Goyal (2018) and Klapova (2011), which employed both constructs, respectively. Gamification as a direct antecedent of competitiveness can be expressed as follows:

Competitiveness $=f($ Gamification $)$

Gamification $=f(P R O D E V G$, MASACTG, CUSERVG $)$

Competitiveness $=\beta 0+\beta 1($ PRODEVG $)+$

$+\beta 2$ (MASACTG) $+\beta 3$ (CUSERVG) $+\mu$
Competitiveness $=$ (price, innovation, customer satisfaction, and technological advancement)

Where:

PRODEVG is Product Development Gamification

MASACTG stands for Marketing and Sales Gamification

CUSERVG is Customer Service Gamification

$\beta 0$ is the constant

$\beta 1, \beta 2, \beta 3$ are the coefficient estimators and

$\mu$ is the error term.

Premised on the above discussion, gamification elements are expected to show a positive interaction with the firm competitiveness dimensions. Therefore, the relationship between gamification and firm competitiveness would be directly proportionate.

TABLE 1: Measurements of variables

\begin{tabular}{|l|l|l|}
\hline Latent variables & Observed variable & Studies adapted \\
\hline $\begin{array}{l}\text { Gamification (value } \\
\text { chain) } \\
\text { Product development } \\
\text { Gamification }\end{array}$ & $\begin{array}{l}\text { Credit scoring } \\
\text { Market research } \\
\text { Inter-company collaboration } \\
\text { Credit-sourcing ideas }\end{array}$ & $\begin{array}{l}\text { Stefanel \& Goyal (2018); Querrec } \\
\text { (2015); Sawhney (2006); } \\
\text { Babrovich (2017) }\end{array}$ \\
\hline $\begin{array}{l}\text { Customer service } \\
\text { Gamification }\end{array}$ & $\begin{array}{l}\text { Interactive self-help applications } \\
\text { Catalysing customer behavior } \\
\text { Interactive and responsive } \\
\text { customer communication }\end{array}$ & $\begin{array}{l}\text { Stefanel \& Goyal (2018); Querrec } \\
\text { (2015); Sawhney (2006) }\end{array}$ \\
\hline $\begin{array}{l}\text { Marketing and Sales } \\
\text { Gamification }\end{array}$ & $\begin{array}{l}\text { Need-based cross-selling } \\
\text { Referrals and lead generation } \\
\text { Directed and engaged } \\
\text { marketing } \\
\text { Customer education }\end{array}$ & $\begin{array}{l}\text { Stefanel \& Goyal (2018); Querrec } \\
\text { (2015); Sawhney, (2006). }\end{array}$ \\
\hline Competitiveness & $\begin{array}{l}\text { Innovation } \\
\text { Price } \\
\text { Customer satisfaction } \\
\text { Technological advancement }\end{array}$ & Nafula (2017); Klapova (2011) \\
\hline
\end{tabular}


The structural equation model (SEM) analysis was used to achieve the objectives of the study. These enabled the relationship among variables and their underlying effect to be established. and competitiveness indices fall within the recommended criteria by Hair et al. (2010).

TABLE 2: Normality test

\begin{tabular}{|c|c|c|c|c|}
\hline & & Criteria & Gamification & Competitiveness \\
\hline Normality & $\begin{array}{l}\text { kurtosis } \\
\text { skewness }\end{array}$ & $\begin{array}{l}-10 \text { to } 10 \\
-3 \text { to } 3\end{array}$ & $\begin{array}{c}-0.901 \text { to } 1.987 \\
-1.781 \text { to } .762\end{array}$ & $\begin{array}{l}-.817 \text { to } 0.788 \\
-1.330 \text { to } .993\end{array}$ \\
\hline Multicollinearity & tolerance & $>0.10$ & .672 to 1.054 & 1.052 to 1.061 \\
\hline & VIF & $<10$ & 1.731 to 1.822 & 1.643 to 2.462 \\
\hline $\begin{array}{l}\text { Collinearity } \\
\text { statistics }\end{array}$ & $\begin{array}{l}\text { correlation between } \\
\text { variables }\end{array}$ & $<0.90$ & .395 to .441 & .518 to .622 \\
\hline $\begin{array}{l}\text { Independence of } \\
\text { residual }\end{array}$ & $\begin{array}{l}\text { Cook's distance for } \\
\text { residual }\end{array}$ & $<1.0$ & .266 & .285 \\
\hline
\end{tabular}

Based on the recommendations of Kline (1998), all variables in the normality test achieved the required skewness and kurtosis threshold, i.e. -3 to 3 for skewness and -10 to 10 for kurtosis. Multivariate normality indicates that the combinations of individual variables and specific variables are expected in a univariate sense (Hair et al., 2010). The Cook distance demonstrates that the data is not unduly influenced in the model.

\section{RESULTS}

\subsection{Gamification trend among deposit money banks}

Figure 1 shows the gamification trend among the three categories of deposit money banks. The marketing and sales gamification was found to be the most common gamification strategy employed by international banks, with

TABLE 3: Goodness of fit

\begin{tabular}{|l|c|c|c|}
\hline \multicolumn{1}{|c|}{ Goodness-of-fit model index } & $\begin{array}{c}\text { Recommended } \\
\text { value* }\end{array}$ & $\begin{array}{c}\text { Gamification } \\
\text { dimensions }\end{array}$ & Competitiveness \\
\hline Chi-square/degree of freedom** & $\leq 5.00$ & 2.754 & 3.12 \\
\hline GFI & $\geq .90$ & 0.93 & 0.91 \\
\hline AGFI & $\geq .80$ & 0.88 & 0.89 \\
\hline NFI & $\geq .90$ & 0.92 & 0.91 \\
\hline TLI/NNFI & $\geq .90$ & 0.94 & 0.912 \\
\hline CFI/RNI & $\geq .90$ & 0.911 & 0.95 \\
\hline RMSEA & $\leq .08$ & 0.06 & 0.05 \\
\hline Standardized RMR & $\leq .08$ & 0.04 & 0.08 \\
\hline
\end{tabular}

* According to Hair et al. (2010).

** As recommended by Ullman (2006).

The table above shows that the consistency of fit indices in the measurement model is appropriate. That is, both gamification dimensions
$49 \%$ of members of their staff saying that they are mostly engaged in increasing their marketing and sales efforts to capture more of the 
market. Hence, they are more concerned about cross-selling and providing better services, leading to more referrals and lead generation, customers education, and directed and engaged marketing. National banks are more concerned about employing the customer' service gamification as about $41 \%$ of the respondents who work at national banks emphasised that their banks pay more attention to responsive and customer-driven services. These national banks provide interactive self-help applications, catalyse customer behavior to the bank services, and facilitate interactive and responsive customer communication. When it comes to regional banks, it was revealed that most banks (39\%) in this category are more concerned about increased marketing and sales gamification.
The results show only outsourcing $(\beta=-0.203$ $p=0.000)$, interactive self-help $(\beta=-0.298 p=$ $0.001)$, referrals $(\beta=-0.324, p=0.000)$, direct marketing ( $\beta=-0.262, p=0.001)$, and consumer education ( $\beta=-0.298 p=0.001$ ) as being negatively correlated to innovation. This is so because as the innovation in these segments increases, customer education, direct marketing, referrals, interactive self-help, and credit sourcing decrease in the gamification strategies. In terms of price, the correlation coefficient shows a positive relationship between the dimensions of gamification and price. However, inter-bank collaboration ( $\beta=-0.688, p=0.016)$ and direct marketing $(\beta=-0.262 p=0.001)$ are inversely correlated. That is, as these dimensions increase, the price falls. The results also reveal that gamification

FIGURE 2: Gamification strategy among deposit money banks

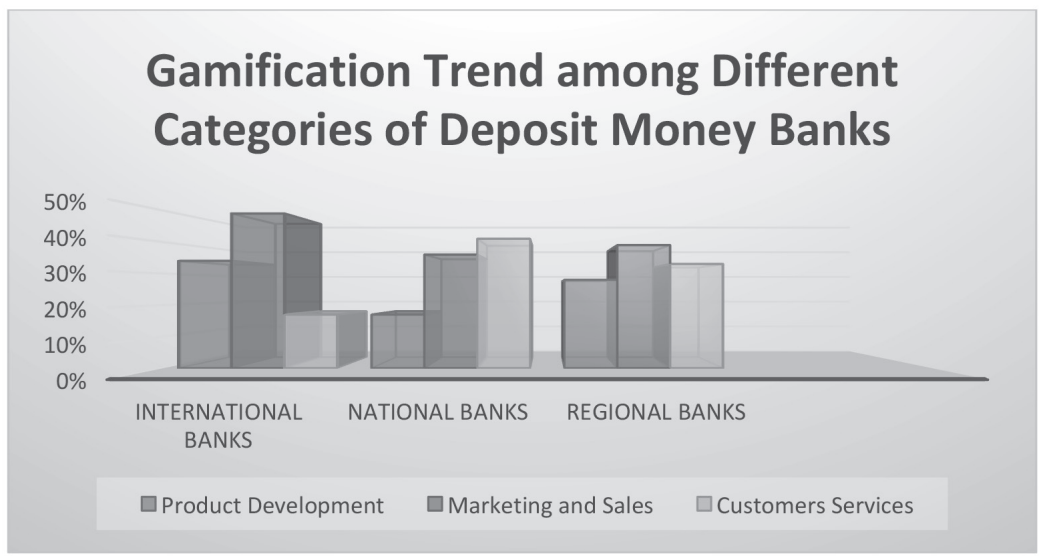

TABLE 4: Correlation matrix

\begin{tabular}{|l|c|c|c|c|}
\hline & Innovation & Price & $\begin{array}{c}\text { Customer } \\
\text { satisfaction }\end{array}$ & $\begin{array}{c}\text { Technological } \\
\text { advancement }\end{array}$ \\
\hline Credit sourcing & -0.203 & 0.528 & Y0.359 & 0.734 \\
\hline Market research & 0.256 & 0.363 & 0.323 & 0.109 \\
\hline Inter-bank collaboration & 0.742 & -0.688 & -0.656 & -0.115 \\
\hline Credit scoring & 0.234 & 0.132 & 0.197 & 0.077 \\
\hline Interactive self-help & -0.298 & 0.906 & 0.947 & -0.127 \\
\hline Catalyzing behavior & 0.124 & 0.081 & 0.072 & 0.737 \\
\hline Cross-selling & 0.036 & 0.631 & 0.531 & 0.811 \\
\hline Referrals & -0.324 & 0.981 & 0.975 & 0.292 \\
\hline Direct marketing & -0.262 & -0.636 & -0.688 & -0.271 \\
\hline Customer education & -0.389 & 0.560 & 0.593 & 0.259 \\
\hline Responsiveness & 0.075 & 0.162 & 0.154 & 0.054 \\
\hline
\end{tabular}

* significance level 0.05 


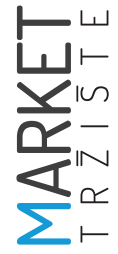

dimensions positively correlate with customer satisfaction, except for inter-bank collaboration $(\beta=0.656, p=0.005)$ and direct marketing $(\beta=-$ $0.688 p=0.000)$. An increase in customer education will result in a reduction of those negatively correlated gamification strategies. The technological advancement analysis found that only interbank collaboration $(\beta=-0.115, p=0.000)$ and direct marketing $(\beta=-0.271 p=0.001)$ are negatively correlated to technological advancement. This means that, as these dimensions increase, technological advancement declines.

\subsection{Hypotheses testing}

TABLE 5: H1 Product development gamification has a significantly effect on firm competitiveness at deposit money banks

\begin{tabular}{|l|c|c|c|c|c|}
\hline & \multicolumn{4}{|c|}{ Firm competitiveness } & \\
\hline Variable & B & SE & $\boldsymbol{\beta}$ & tc & p \\
\hline $\begin{array}{l}\text { Product } \\
\text { development }\end{array}$ & .673 & .0645 & .911 & 14.293 & 0.000 \\
\hline$R^{2}$ & 0.827 & & & & \\
\hline Collinearity & 1.055 & & & & \\
\hline
\end{tabular}

The result in Table 5 exhibits a remarkable and positive relationship ( $\beta=0.911$ ) between the product development gamification and firm specifically the product development gamification drives firm competitiveness since the value falls between the estimates agreed. This also indicates that the product development gamification is a driver of firms' competitiveness. The unstandardised coefficient $(B=0.673$ ) shows that for every unit increase in product development, competitiveness increases by 0.673 units. The t-value ( $\mathrm{t}$-value $=14.293, \quad \mathrm{p}=0.000$ ) establishes that the product development gamification is a significant predictor of competitiveness. Hence, the alternative hypothesis is accepted. The result confirmed that the product development gamification significantly affects the firm competitiveness of deposit money banks.

Path analysis: product development gamification and competitiveness in deposit money banks

Figure 1 reveals the deviation variability and all measured paths between product development and firm competitivness. The model attained a fitness fit of $\mathrm{CMIN}=2.86, \mathrm{p}=0.00$; RMSEA $=0.005, \mathrm{GFI}=0.95, \mathrm{CFI}=0.97, \mathrm{IFI}=0.98$ ).

Figure 3 shows the path analysis of the product development gamification effect on deposit money banks' financial competitiveness. The findings indicate that credit sourcing $(\beta=0.810)$ is the most significant observed product de-

FIGURE 3: Path analysis of the product development gamification and firm competitiveness

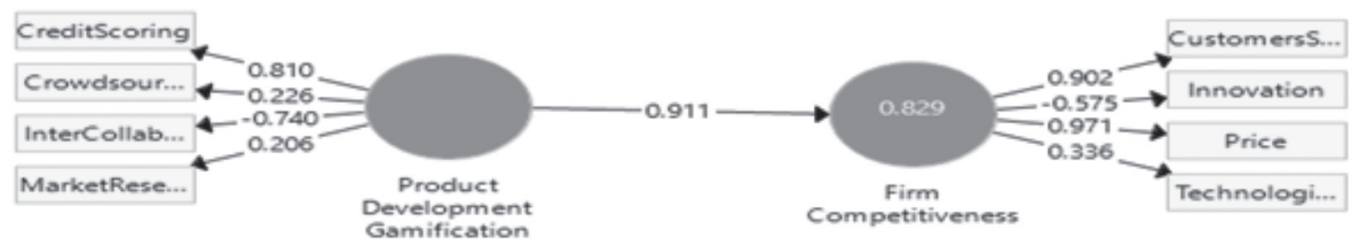

competitiveness. The determination coefficient $(R 2=0.827)$ indicates that product production explains the $82.7 \%$ deviation in competitiveness. The standard error ( $\mathrm{SE}=0.0645$ ) shows that the model is a good match by demonstrating how velopment gamification measure influencing competitiveness. The path analysis also found customer satisfaction ( $\beta=0.902$ ) to be the most significant construct in competitiveness influenced by product development. 
TABLE 6: H2 Marketing and sales gamification have a significant effect on firm competitiveness at deposit money banks

\begin{tabular}{|l|c|c|c|c|c|}
\hline & \multicolumn{4}{|c|}{ Firm competitiveness } & \\
\hline Variable & B & SE & $\boldsymbol{\beta}$ & tc & P \\
\hline $\begin{array}{l}\text { Marketing } \\
\text { and sales } \\
\text { gamification }\end{array}$ & 0.943 & 0.011 & 0.934 & 87.785 & 0.000 \\
\hline$R^{2}$ & 0.890 & & & & \\
\hline Collinearity & 1.024 & & & & \\
\hline
\end{tabular}

Table 6 shows the existence of a strong and influential correlation ( $\beta=0.934)$ between the marketing and sales gamification and firm competitiveness. The determination coefficient $(R 2=0.890)$ indicates that marketing and sales gamification practices explain the $89 \%$ difference in competitiveness. The standard error ( $\mathrm{SE}=0.011$ ) points to the model being a good match by demonstrating how precisely
Path analysis: marketing and sales gamification activities and competitiveness at deposit money banks

Figure 2 shows the deviation variability and all measured paths between the marketing and sales gamification and firm competitiveness. The model achieved a fitness fit of $C M I N=3.22$, $\mathrm{p}=0.00 ; \quad \mathrm{CFI}=0.98, \quad \mathrm{RMSEA}=0.04, \quad \mathrm{GFI}=0.97$, $|\mathrm{F}|=0.97$.

Figure 4 shows the path analysis of the effect of the marketing and sales gamification on the dimensions of competitiveness of deposit money banks. The findings point to referrals and lead generation ( $\beta=0.903$ ) as the most significant observed measure of the marketing and sales gamification influencing firm competitiveness. The path analysis also confirms that price ( $\beta=0.962)$ to be the most significant construct in competitiveness influenced by the marketing and sales gamification.

FIGURE 4: Path analysis of marketing and sales gamification on firm competitiveness

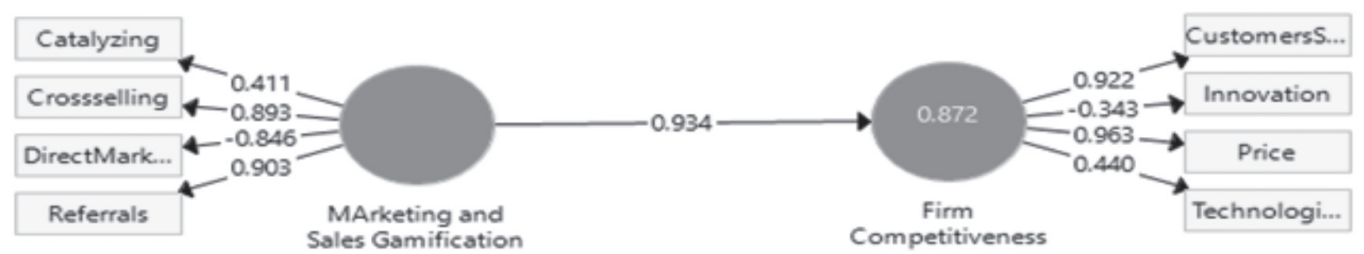

the marketing and sales gamification predicts firm competitiveness because the value falls between the predictions agreed. This also indicates that the marketing and sales gamification is a driver of firm competitiveness. The unstandardised coefficient $(B=0.947)$ shows that for every unit increase in the marketing and sales gamification, competitiveness increases by 0.943 units. The t-value (t-value $=87.785, p=0.000$ ) establishes that the marketing and sales gamification significantly affects competitiveness. Hence, the alternative hypothesis is accepted. The result confirmed that the marketing and sales gamification significantly affect firm competitiveness at deposit money banks.
TABLE 7: H3 Customer service gamification has a significant effect on firm competitiveness at deposit money banks

\begin{tabular}{|l|c|c|c|c|c|}
\hline & \multicolumn{4}{|c|}{ Firm competitiveness } & \\
\hline Variable & B & SE & $\boldsymbol{\beta}$ & TC & p \\
\hline $\begin{array}{l}\text { Customer } \\
\text { service }\end{array}$ & 0.914 & 0.013 & 0.919 & 71.775 & 0.000 \\
\hline$R^{2}$ & 0.843 & & & & \\
\hline Collinearity & 1.024 & & & & \\
\hline
\end{tabular}

The results provided in Table 7 show a positive and strong relationship $(\beta=0.919)$ between the customer service gamification and firm competitiveness. The determination coefficient ( $R 2=0.843)$ indicates that the customer service 
gamification explains $84.3 \%$ of variability in competition. The standard error ( $\mathrm{SE}=0.013$ ) confirms that the model is a good match by demonstrating how precisely the customer service gamification forecasts consumer experience because the value falls between the estimates agreed. This also indicates that the customer service gamification is a driver of firm competitiveness. The unstandardised coefficient ( $B=0.914$ ) shows that for every unit increase in customer service competitiveness increases by 0.914 units. The $t$-value ( $t$-value $=71.775, p=0.000$ ) points to the fact that the customer service gamification is a significant predictor of competitiveness. Therefore, the null hypothesis is rejected, while the alternative hypothesis is accepted. The result establishes that the customer service gamification has a significant effect on firm competitiveness at deposit money banks.

Path analysis: customer service gamification and competitiveness at deposit money banks

Figure 4 shows the error variance of the calculated paths between customer service and firm competitiveness. The model achieved a fitness fit of $C M I N=2.61, p=0.00 ; G F I=0.95$, RMSEA $=0.04$, $|\mathrm{F}|=0.97, \mathrm{CF} \mid=0.98$.

Figure 5 shows the path analysis of the effect of the customer service gamification on the di- mensions of competitiveness of deposit money banks. The findings indicate that interactive selfhelp applications $(\beta=0.898)$ are the most significant measure of customer service observed which influences competitiveness. The path analysis also confirms price $(\beta=0.991)$ as the most significant construct in competitiveness influenced by customer service.

Path analysis of the combined effect of gamification dimensions on the competitiveness at deposit money banks

The error variance of the calculated paths between gamification and firm competitiveness is provide in Figure 6. The model had a fitness fit of $C M I N=4.81, p=0.00 ; G F I=0.98$, RMSEA=0.004, $\mathrm{IFl}=0.98, \mathrm{CF}=0.97$.

Figure 6 shows the combined effect of gamification dimensions on the competitiveness of deposit money banks. According to the analysis, the customer service gamification $(\beta=0.564)$ has the most significant effect on bank competitiveness, while price $(\beta=0.989)$ is the most significant construct of competitiveness when the gamification dimensions are combined. The result also shows that when these dimensions are combined, the impact on bank competitiveness is positive and highly significant $(\beta=0.971)$

FIGURE 5: Path analysis of customer service gamification on firm competitiveness

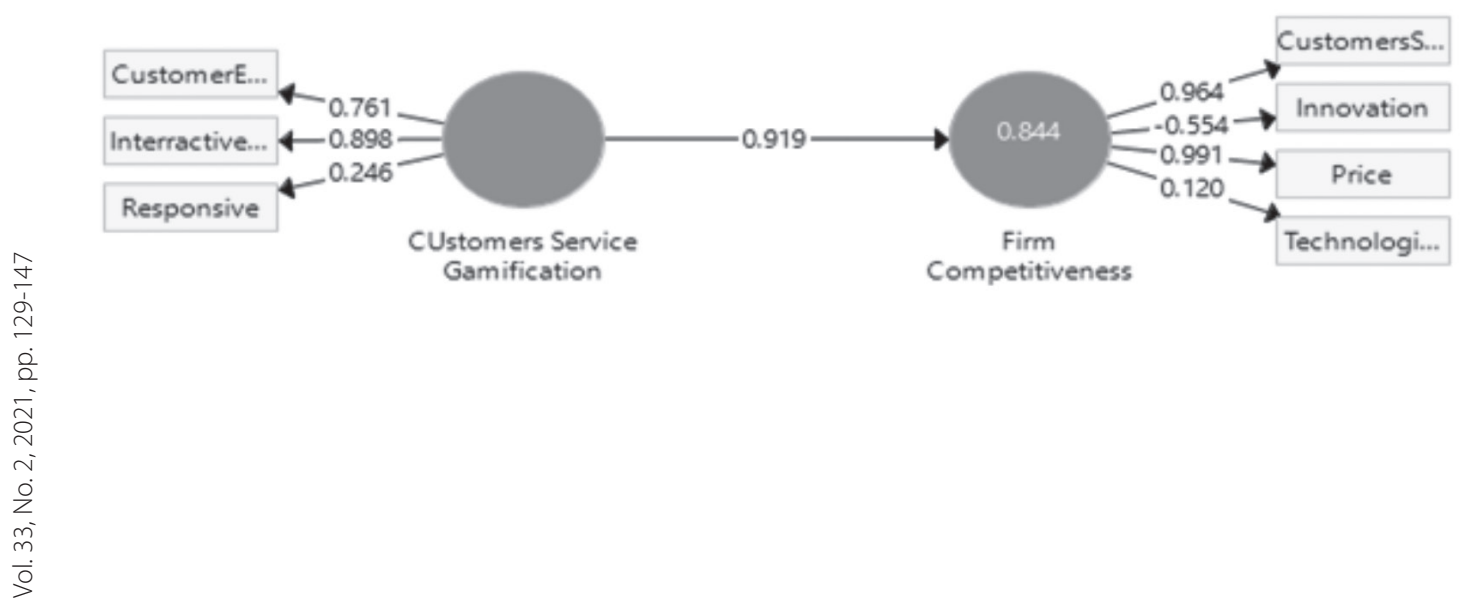


FIGURE 6: Path analysis of combined effect

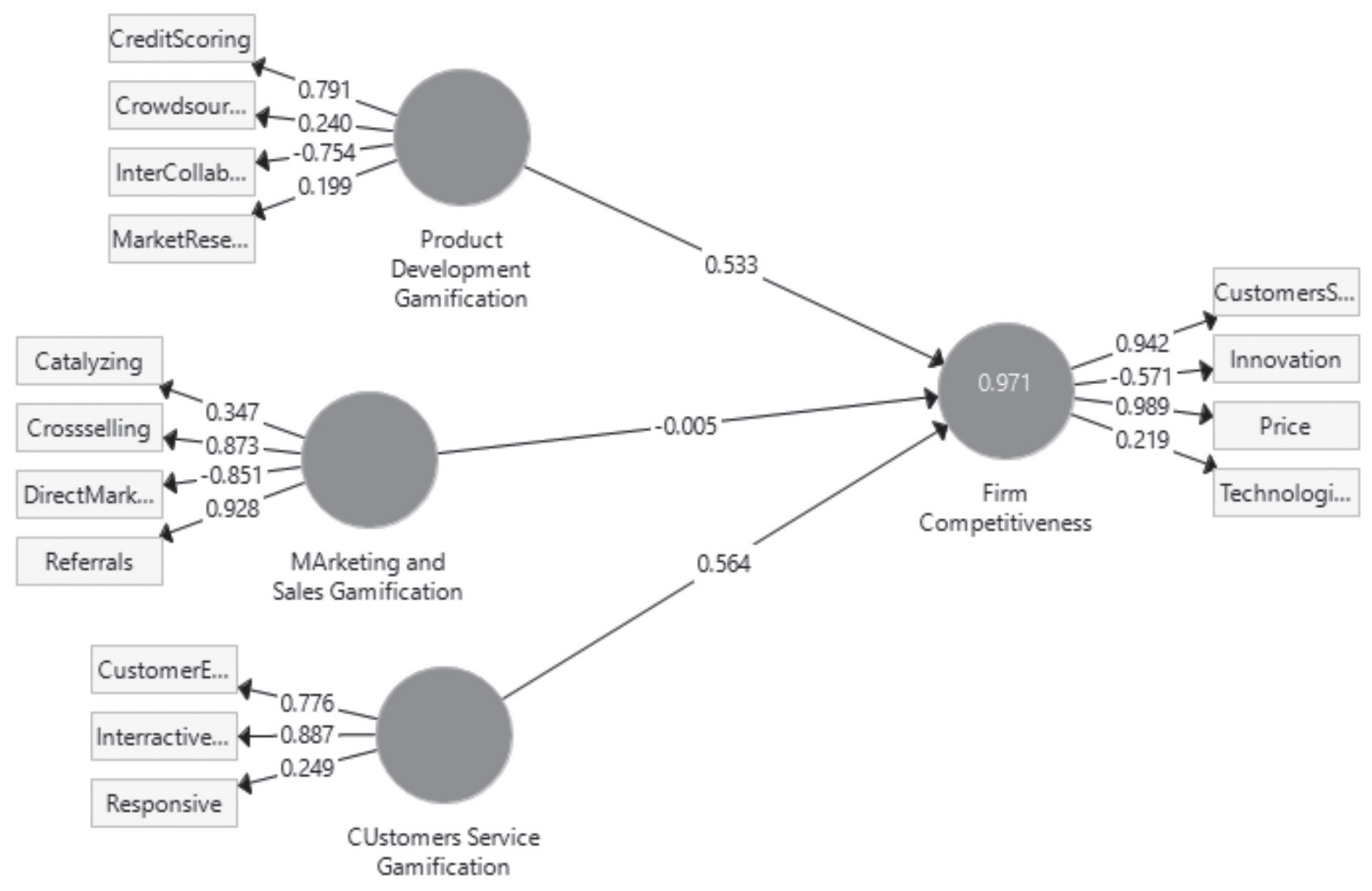

\subsection{Discussions of results}

The results of this research study illustrate the gamification trend among the deposit money banks. International and regional banks were found to be more concerned about implementing marketing and sales activities as a gamification strategy to influence and maintain competitiveness in the market. National banks, on the other hand, resort to the customer service strategy to achieve competitiveness in the marketplace. This supports the assertions made by Vorlova (2015) that any firm's gamification strategy is influenced by the firm's existing experience and drive.

From the analysis of Hypothesis 1, it can be inferred that the product development gamification significantly affects the competitiveness of deposit money banks by adding value to customers; therefore, deposit money banks should develop products tailored to meet customer needs. The path diagram reveals that deposit money banks should first pay attention to credit sourcing when developing their products be- fore any other dimension. Customers should be the driver of competitiveness at deposit money banks and of their product development to meet customer expectations. The study corroborates the opinion of Branovich (2017) and Worimegbe et al. (2020), who believe that creating new and interactive services could lead to better performance in a firm.

The analysis of Hypothesis 2 showed that the marketing and sales gamification is a significant driver of competitiveness at deposit money banks. Banks should work on referrals and lead generations while strategising because those are the most significant marketing and sales gamification drivers affecting competitiveness. Deposit money banks' competitiveness should be premised on prices when sales and marketing activities are involved. This is pivotal to the firm and creates a cost leadership platform for banks in a dynamic environment. The findings support Oleksyuk (2019), who found in a study that marketing and sales are critical to enhancing the firms' potential to perform better. 


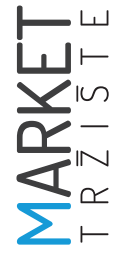

The results of analysis of Hypothesis 3 point to the high importance of customer service in achieving competitiveness. In strategising and making the customers the focus of the organization's activities, deposit money banks should pay more attention to interactive self-help applications. This will make them more efficient and proactive while creating a new and exciting experience for their customers. This corroborates the position of Worimegbe et al. (2020) that the firms' main reason for gamification should be to drive customers services. However, it is expected that deposit money banks should focus on competitive pricing as this will give them the edge over their competitors.

The combined effect analysis indicates that, in gamifying, customer service should be the priority for deposit money banks since that dimension has the most significant effect on competitiveness. This is in line with the suggestions of Mruthyanjaya and Vadiya (2019), and Warnick and Bui (2019), explaining that gamification should be employed to achieve corporate goals both in the long run and in the short run. Also, the result supports the views of Worimegbe et al. (2020), who claimed that existing businesses should implement gamification to increase consumer loyalty, obtain consumer commitment, achieve competitiveness, and enhance employee efficiency.

\subsection{Theoretical contribution}

The findings of this study support the meansend theory, which is based on the idea that the disposition of customers to use a product or service can be viewed through product attributes, personal values, and consequences of the application represented by a hierarchical model (Copetti, 2005; Kaminski \& Prado, 2005; Dibley \& Baker, 2001). Furthermore, the findings of the study explain that customers view services as a means to meeting important ends while also attempting to describe how the choice of service enhances the desired achievement of an end, which in this case is firm competitiveness. The cooperative link in the means-end model makes possible the analysis and interpretation of how customers perceive services as self-relevant, and goes beyond functional attributes to add value to the customers. The study supports the idea that values are the major factors in the customer purchase pattern and that, in order for firms to attain competitiveness, attention should be paid to the product development, marketing and sales, and customer service gamification. The study established that there is a link between service attributes and the consequences of such customer actions. Customers perceive services offered and delivered as satisfying and adding value based on their functionality. There is a need for financial firms, and especially deposit money banks, to have an integrated robust strategy that incorporates product development, sales and marketing activities, and customer service gamification in order to achieve competitiveness. Deposit money banks should pay attention to credit sourcing, referrals, and interactive self-applications in the gaming process so as to remain relevant in the sector.

\section{CONCLUSIONS}

The study establishes that gamification is a significant driver of competitiveness at deposit money banks. By implementing the gamification strategy, deposit money banks will engage their existing and potential customers more, thereby creating a new and exciting experience that will increase their competitiveness. The dimensions of gamification are all significant drivers of firm competitiveness. The study also concludes that credit sourcing, referrals by customers, and interactive self-help applications are essential aspects of gamification driving the firm's competitiveness. For a firm to be competitive, it has to pay attention to its pricing strategy in the market. This measure (price) provides additional critical information for the firm and can indirectly reveal the weaknesses, strengths, and opportunities available in its business operations. Based on the study's findings, it is recommended that deposit money banks focus on gamification to achieve and maintain com- 
petitiveness. More attention should be paid to credit sourcing, referrals and lead generation, and self-help application.

\section{Limitation of the study and suggestion for future research}

This study examined the impact of gamification on firm competitiveness in the banking sector. Non-financial measures of competitive- ness were employed to arrive at conclusions. The scope was limited solely to the examination of the banking sector in the financial market. It is suggested that future research should focus on other sectors of the financial industry and other industries in the economy. The impact of gamification on the macro- and microeconomic performance should also be considered.

\section{References}

1. Ahmad, K., \& Zabri, S. M. (2016). The application of non-financial performance measurement in Malaysian manufacturing firms. Procedia Economics and Finance, 35, 476-484.

2. Amato-McCoy, D. (2005). Creating virtual value. Bank Systems and Technology, 1(22), 8-9.

3. Babrovich, N. (2017). How to use gamification in banking to engage customers and employees. Retrieved from https://www.scnsoft.com/blog/gamification-in-banking (accessed May 2021).

4. Biloch, A., \& Lofstedt, A. (2013). Gamification and performance management, a tool for driving competitiveness through employee engagement. Master's thesis. Luleå: Lulea University of Technology.

5. Copetti, C. L. P. ( 2005). Valor para o cliente: análise de congruência sob a perspectiva do consumidor final e da comunicação. Master's thesis. São Leolpodo: Unisinos University.

6. Dibley, A., \& Baker, S. (2001). Uncovering the links between brand choice and personal values among young British and Spanish girls. Journal of Consumer Behavior, 1(1), 77-93.

7. Frohberg, K., \& Hartmann, M. (1997). Comparing measures of competitiveness. Institute of Agricultural Development in Central and Eastern Europe, No. 2, http://nbn-resolving.de/urn:nbn:de:gbv:3:2-22616 (accessed January 2021).

8. Gartner, B. (2011). Gartner Says By 2015, More than 50 percent of organisations that manage Innovation Processes will gamify those processes. Retrieved from https://www.gartner.com/newsroom/ id/1629214 (accessed december 2020).

9. George, D., \& Mallery, P. (2000). SPSS for Windows step by step: A simple guide and reference $11.0\left(4^{\text {th }}\right.$ ed.). Boston, MA: Springer.

10. Gomanthi, S. (2017). A review on gamification and its potential to motivate and engage employees and customers: Employee engagement through gamification. International Journal of Sociotechnology And Knowledge Development, 9(1), 42-50.

11. Gutman, J. (1981). A means-end model for facilitating analysis of product markets based on consumer judgement. Advances in Consumer Research, 8, 116-121.

12. Hair, J., Anderson, R., Tatham, R., \& Black, W. (2010). Multivariate data analysis. Upper Saddle River, $\mathrm{NJ}$ : Prentice-Hall International.

13. Huotari, K., \& Hamari, J. (2012). Defining gamification: A service marketing perspective. Proceedings of the $16^{\text {th }}$ International Academic MindTrek Conference, Tampere: ACM.

14. Joudrey, S. (2019). Best gamification examples in finance. Retrieved from https://hedgetrade. com/best-gamification-examples-in-finance/ (accessed December 2020).

15. Kaminski, S. R., \& Prado, P. H. M. (2005). O consumo de música segundo modelo de cadeias de meios-fim: uma aplicação da association pattern technique (APT). Anais do Encontro Nacional dos Programas de Pós-Graduação em Administração, Brasília (Brasil). 
16. Klapalova, A. (2013). Knowledge, skills and competencies of hospitality companies in the south Moravian region. Journal of Competitiveness, 5(3), 51-66.

17. Klaus, P., \& Maklan, S. (2013). Towards a better measure of customer experience. International Journal of Market Research, 55(2), 227-246.

18. Kline, R. B. (1998). Methodology in the social sciences. Principles and practice of structural equation modelling. London: Guilford Press.

19. Leão, A. L. M. S., \& Mello, S. C. B. (2003). Conhecendo o 'valor do cliente' de um jornal on-line. Revista de Administração de Empresas, 43(3), 22-35.

20. Mann, J. (2013). Social Business Transformation through. Gamification. International Journal of Managing Information Technology, 5(3), 9-19.

21. Marín, L., Rubio, A., \& Maya, S. R. (2012). Competitiveness as a strategic outcome of corporate social responsibility. Corporate Social Responsibility and Environmental Management, 19(6), 364-376.

22. Maune, A. (2014) Competitive intelligence and firm competitiveness: An overview. Corporate Ownership and Control, 12(1), 533-542.

23. Mruthyanjaya, R., \& Vaidya, R. (2019). Gamification and resource pooling for improving operational efficiency and effective management of human resources: A case study with an eCommerce company. International Journal of Management, 10(6), 76-87.

24. Mulvey, M. S., Olson, J. C., Celsi, R. L., \& Walker, B. A. (1994). Exploring the relationships between means-end knowledge and involvement. Advances in Consumer Research, 21, 51-67.

25. Nafula, M. K. (2017). Effect of innovation on firm competitiveness: A study of small and medium enterprises in the manufacturing sector in Nairobi City County, Kenya. https://ir-library.ku.ac.ke/ handle/123456789/18441 (accessed December 2020).

26. Ng, W. (2011). Let's play games. Retrieved from: www incentivemag.com (accessed December 2020).

27. Oleksyuk, A. (2019). How to use gamification in banking. https://medium.com/swlh/ how-to-use-gamification-in-banking-7f55e1b3c7a9 (accessed December 2020).

28. Perusic, J. B. (2008). The relevance of Game Theory in e-Business. Rijeka: Universitry of Rijeka. Retrived http://ecenter.fov.unimb.si/merkurday2008/Papers/Jelena_Perusic.pdf. (accessed December 2020).

29. Porter, M. E. (2008). The five competitive forces that shape strategy. Harvard Business Review, 86, 79-93.

30. Querrec, E. (2015). Opportunity for banks to utilise gamification as a tool to promote financial education to children. PhD Thesis. Birmingham: Core University. Retirived from https://core.ac.uk/ download/pdf/38120516.pdf (accesed April 2021).

31. Rodrigues, L. F., Costa, C. J. \& Oliveira, A. (2014). The adoption of gamification in e-banking. Proceedings of the 2013 International Conference on Information Systems and Design of Communication (ISDOC '13). Lisbon (Portugal), July 2013.

32. Sawhney, M. (2006). Going beyond the product. defining, designing and delivering customer solutions. The service-dominant logic of marketing: dialogue, debate and directions. Armonk, NY: M.E. Sharpe.

33. Stefanel, M., \& Goyal, U. (2018). gamification of financial services: current trends and future possibilities. Retrived from: http://apis.pe/wpcontent/uploads/2018/10/Apis_Partners_Gamification_ of_FS.pdf?x54915 (accessed December 2020).

34. Ullman, J. B. (2006). Structural Equation Modeling: Reviewing the Basics and Moving Forward. Journal of Personality Assessment, 87(1), 35-50.

35. Vilanova, M., Lonanzo, J., \& Arenas, D. (2009). Exploring the nature of the relationship between CSR and competitiveness. Journal of Business Ethics, 87, 57-69. 
36. Vriens, M., \& Hofstede, T. (2000). Linking attributes, benefits, and consumer values. Marketing Research, 12(3), 4-10.

37. Warnick, V., \& Bui, H. (2019). Gamification in management: Analysis and research directions. International Journal of Serious Games, 6(2), 57-74.

38. Worimegbe, P. M., Worimegbe, T. M., \& Abiola-Oke, E. (2020). Gamification and Customers Experience in the Hospitality Industry. Journal of Tourism and Services, 21(11), 71-87.

39. Xu, F., Weber, J., \& Buhalis, D. (2017). Serious games and gamification of tourism. Tourism Management, 60, 244-256.

40. Yusuff, S. A., Oladimeji, M. S., Ahmodu, O. L., \& Adeniyi, A. (2019). Gamification on sales force performance in Nigeria bottling company. Games Review, Conscientia Beam, 4(1), 1-8. 